\title{
Achieving Excellence in Art Gallery Management in a Global Pandemic
}

\author{
Best Ochigbo a, Ime Ukim a,* \\ a Department of Fine and Industrial Arts University of Uyo, Nigeria. \\ *Corresponding author Email: imeukim@yahoo.com \\ DOI: https://doi.org/10.54392/ajir2213 \\ Received: 21-11-2021; Revised: 20-02-2022; Accepted: 23-02-2022; Published: 02-03-2022
}

\begin{abstract}
The recent global pandemic, Covid-19, has crippled the activities of virtually all sectors of the world's economy, including art. This has resulted in low patronage and, in some cases, a total shutdown of art galleries in the world. Managing an art gallery has, therefore, become a herculean task. This discourse, therefore, takes a look at achieving excellence in art gallery management in a global pandemic. Its objectives are to find ways of achieving excellence in art gallery management in a global pandemic; advance possible ways or means of creating innovative management strategies, and ascertain the role of art management in the visual art sector for effective service delivery. The paper relied on library and internet sources and participant observation research methods. The paper concludes that transparency, resilience, and speed are required to achieve excellence in art gallery management in a global pandemic. It is recommended that Art galleries should evolve by employing online access to doing business alongside traditional methods.
\end{abstract}

Keywords: Art Gallery Management, Covid-19, Online Sales, Pandemic.

\section{Introduction}

It is pertinent here for us to understand what an art gallery stands for. From a common perspective, a gallery would pass for a place that exhibits and sells artworks of different artists (Koshal, 2011). Habelsberger and Bhansing (2021) aver that gallery is the umbrella term for both contemporary art galleries on the primary market and art dealers on the secondary market - the primary market being artworks by contemporary artists that enter the market for the first time, either for direct sales by the artist to buyers or through a contemporary art gallery, while secondary market refers to artworks that are resold either by auction houses or dealers, (Velthuis, 2011). It, however, goes beyond exhibition and sales of artworks. At the risk of oversimplification, an art gallery is a room or a designated building in which visual arts are displayed for the purpose of public viewing, elucidation, sales and cultural pride of a nation's history or a people's identity; as well as for the purpose of education. Galleries play a vital role on the part of both the producer of art and the buyer. Galleries serve as gatekeepers that select and promote good quality artists (VanMiegroet et al, 2019) and also as art advisors when they play advisory role to buyers by informing them of new trends and emerging artists, and also connecting them to curators, artists and other stakeholders, (Fillitz, 2014). To this end, the galleries act as intermediaries committed to creating art's symbolic and economic value (Velthuis, 2004). Conversely, art gallery management deals with the collection, documentation, custody, installation and handling of visual art in any given environment, be it home, museums, galleries and other public spaces where visual art objects are placed on display. Gallery management requires a wide range of strategic, administrative, innovative and creative skills.

The gallery's success both in its artistic development and in its financial prosperity is mainly dependent on the manager who is charged with the responsibility of its day-to-day running. The Manager is saddled with the promotion, marketing and sales of artists' works. Primarily, the gallery functions to make money as a business entity. Its primary function is to bridge culture and community through excellence in visual art. It is meant to engage, stimulate, and facilitate visual art development, presentation, and preservation. 
A pandemic is a disease outbreak that spreads across countries or continents (Robinson, 2020). It is an epidemic that covers a wide geographic area and affects an exceptionally high proportion of the world's population. It spreads so rapidly, leaving a trail of casualties behind. In the case of the present Covid-19, the cause and probable containment strategy were not immediately known. It has wrought economic destruction, surging job losses, skyrocketing bankruptcy cases, and a looming economic recession. It has thrown masses of businesses into a tailspin (Carnell, 2011). Due to its dangerous nature and attendant risks, restrictions were imposed on citizens in virtually every country, creating a lot of concerns. Hence businesses, travels, hospitality, recreation, education, and even governance were presumptuously affected. The visual art sector was not an exemption. It had a tremendous impact on the art market. For months, mobility was restricted for all art market participants and events, and art fairs worldwide were canceled (Gerlis, 2020). The pandemic has affected many supply chains as artists and art gallery operators are the most affected due to the total shutdown of business over time. Art Gallery sales dipped by 36 percent on average in the first half of 2020 (Carnel, 2021). This is the concern of this discourse as we are faced with an unusual scenario. Hence, the need to look at how the pandemic has impacted art gallery management to proffer ways to achieve excellent control to get the gallery back to shape despite the pandemic.

This paper aims to find ways of achieving excellence in art gallery management in a global pandemic; advance possible ways or means of creating innovative management strategies, and ascertain the role of art management in the visual art sector for effective service delivery. The paper relied on library and internet sources and participant observation research methods. As participants in gallery management, the experience here is mainly from an insider point of view, coupled with a survey of galleries, which provided clues for the mass layoffs and closures associated with the fragile finances of businesses (Bartik et al, 2020). This paper is modeled after the Adaptation Theory propounded by Charles Darwin, as cited by (King 2018). The theory deals with an organism's ability to adapt to changes in its environment and adjust accordingly over time. Although the theory was propounded from the perspective of Biology, it is also applicable to other situations where change is inevitable. Having experienced change caused by the dreaded Covid-19 pandemic, art galleries must adapt to the prevailing situation and adjust accordingly to achieve excellence in the present global pandemic.

\section{Impact of the Pandemic on Art Galleries}

The impact of the pandemic from inception to date is better imagined, as the crisis has already transformed into an economic and labour market shock, not only supply of goods and services but also demand and investment (International Labour Organisation, 2020). It further reiterates that generally, the pandemic's impact on the world of work has been both devastating and far-reaching, ranging from losses in working hours, translating into increased unemployment, inactivity and informality to diminishing labour and business income, enterprise closures and bankruptcies disrupting of supply chains; as a result, exacerbated poverty. As regards arts related areas, this global emergency has had a sudden and substantial impact on art practice and the artists. The cultural heritage sectors are equally submerged in the prevailing conditions ravaging the globe (Nyah et al, 2020). For instance, like many industries that rely on in-person interaction, the world of art has been severely impacted by the pandemic of a decline in art sales across the globe. Galleries had to increase layoffs. The scenario is such that employment, sales, art fairs/exhibitions and gallery priorities have been heavily affected (Art Basel, 2020).

Employment: Generally, arts and culture have experienced significant economic setbacks from Covid-19. Across the spectrum of artistic and creative endeavors, restrictions on gatherings, changes in consumer behavior (voluntary or otherwise), and severe unemployment have taken a devastating toll on the sector (Gulbert \& Hyde, 2021). For instance, the National Gallery of Art in Nigeria technically laid off more than half of her workforce in her outpost offices. More galleries may risk closure, especially private galleries, posing significant losses to the broader art economy.

Sales: It has had and will continue to have a critical impact on sales in the art gallery sector - given the industry's relevance on events, travels and discretionary spending, sales contracted for both operators and artists due to so many restrictions, for instance, (Sutton 2020), citing a study (McAndrew 2020), avouches that galleries sales generally dropped $36 \%$ on average in the first six months of 2020 compared to the same period in 2019. 
Online Sales: When the Covid-19 pandemic forced galleries to shut their doors, digital exhibitions became the order of the day, and artworks started being sold online (Belcove, 2021). This saw accelerated growth as it offers alternative way for continuity in sales. Collectors purchased works online through private and public galleries' virtual space. Galleries with online viewing rooms were most successful. It was difficult for galleries that did not have this tradition of online sales before the pandemic.

Art Fairs: Sales were reduced for lack of physical events through art fairs. There have been countless museum and gallery closures and canceled art fairs, even those scheduled for early 2021 were rescheduled. Both Art Basel and Frieze have rescheduled theirs (Team Artenal, 2020). However, auction houses are now hosting online auctions where people can bid from the comfort of their homes, and art galleries have recently started creating virtual showrooms where artworks are displayed and offered for sale (Sidorova, 2010 cited in Habelsberger \& Bhansing, 2021). This brought about the highest sales decline in the gallery sector. This is where online viewing rooms became effective as prices were of the essence when out rightly attached to works. Nevertheless, online forums could never replace or replicate the experience of physical fairs. Art fair sale is best with in-person.

Gallery Priorities: The priority of any gallery is to organize art fairs, exhibitions, tours and widen the geographical base of their clients. This priority has eluded many galleries as these have shifted markedly during the pandemic.

The Way Forward: Sales decreased significantly in 2020, but it is getting traction in 2021 as the economy opens up. There are new breed collectors through online sales who hitherto do not attend exhibitions. But the pandemic has increased their interest in the art collection. All thanks to addiction to the Internet.

The way forward is to explore both virtual and in-person sales through the in-house exhibition as things ease, given that the business and social context of art galleries, as well as the specific characteristics of the art market, make it challenging to sell artworks online while maintaining the traditional gallery business model. Using digital channels as an additional component amplifying the business model (Ernst and Young, 2012) becomes extremely necessary. Through this, collectors' interest and confidence in the art market can be advanced.

The internet has facilitated the global visibility of art market participants, making it easier for art collectors and buyers to access a boarder range of offering on an international level (Habelsberger \& Bhansing, 2021). This is why galleries must, as a matter of necessity, create online access while not abandoning traditional methods. The cloud is paramount today. In the art world, run by gallery operators, acceleration of access was dramatically fast forwarded by the circumstances of the time. Art galleries in a pandemic have to evolve, or they perish. The need to provide online collaborative tools to staffers cannot be over-emphasized, hence the need for affordable and accessible cloud-based tools for gallery management. Galleries that saw these tools as future possibilities ensured that the desires of the future became the needs of today. Online galleries are trending globally presently.

The Covid-19 pandemic forced artists and gallery operators worldwide to move past traditional structures (even though it has never been all-inclusive) create and adapt digital communities with new audiences. With the move to online exhibitions and virtual exhibitions and programmes, the hitherto restriction imposed by geographical differences, cost of travel and precious time have been altered or reduced as an art enthusiast and collectors can do the business from the comfort of their homes without having to be physically present in a show. Today we have augmented reality where buyers can roam various galleries from a single spot without traveling to those galleries.

\section{Art Gallery Management}

Art galleries all over the world started the year 2020 with optimism, Art galleries were booming, programs and expectations were at an all-time high, but in the first quarter into the year, when art galleries felt would be one of the most vital business years, the coronavirus changed the narrative. For months, there was the restriction of movement for all art market participants, and events and art fairs worldwide were canceled. As a result, art galleries and other art market players had to consider alternatives to their current strategies and activities to reach people during this period of restriction (Gerlis, 2020). Who would have presumed that things would have upturned rapidly as both private and public art galleries struggle to figure out what to do? 
What is the best way to lead and manage art galleries during this pandemic era? That is the question in the minds of art gallery managers worldwide as they decide what to do next. One thing is sure: How art galleries respond to the mutating Corona Virus today will define their future success. What galleries need to do to survive can be summed up in three words: "transparency, resilience and speed". To build an art gallery's transparency, resilience and speed do not happen by chance. It depends on the direction of managers' thoughts in cultivating the right culture.

The culture you cultivate and nurture depends on how transparent you are and how imaginative you are, as well as how fast you can move. We shall take the survival strategies of transparency, resilience, and speed to situate our discourse.

Transparency: Transparency is a fundamental aspect of successful workplaces. It is openness between the manager and those under them (Gain, 2021). For a gallery to thrive, there must be transparency between the manager and his employees and equally and more importantly between the manager and the gallery's affiliates like the artists. Trust in management is critical during a pandemic like the one we find ourselves in. Transparency is key to leading and managing art galleries during this pandemic because transparency builds trust.

The question is, how can art gallery managers build trust? Trust is founded on two attributes: competency and ethical behavior. Competency is seen in the manager's ability to deliver on set goals like the gallery's role in the growth and advancement of the artists. At the same time, ethical behavior is the ability to do what is suitable for the people (artists) and society. The attitude galleries managers bring into the art business will define their brand. This is the best time to build a culture of transparency and trust between art gallery operators and artists and to step up to do what is right for their clients.

Resilience: Resilience, the ability to recover quickly from setbacks and adversity (Turner, 2022.), that ability to be successful in the midst of a high-pressured, fast-paced, and continuously changing environment, is a culture that must be taught by Art gallery management, especially at this time of global economic setback caused by Covid19 pandemic. Art gallery operators can build resilience by approaching the pandemic in three key areas; respond, recover, and thrive.

Art galleries, especially public galleries, should have passed the response stage; as this stage is all about the steps, they have taken to prepare for the pandemic and the specific actions they have taken to effectively handle the business of art gallery management, employees, and affiliates amid the onset of the outbreak. If a gallery has not done so, this is the time to put together a business continuity plan with specific tasks designated to help ensure an art gallery's resilience during this pandemic. Tasks expected in this stage include developing and implementing a crisis communication plan, forming a task force, and making flexible working arrangements for employees and affiliates.

Art galleries' ability to survive the pandemic depends on the resilience of the art sector and its workforce. Galleries should encourage creativity and innovation, given that creativity, according to Jeffrey (2020), is the primary reason for our exceptional adaptability. It enhances our ability to connect abstract ideas and develop novel solutions - solutions that build resilience. To devise ways and means of keeping the gallery afloat amidst the pandemic is a sure way of building resilience, for instance, galleries exploiting digital channels is a way and means of continuing in business regardless of the pandemic. Compared to other consumer goods markets, art galleries which have long been reluctant to innovate through digitalization have been forced by the pandemic to reconsider the role of digital channels (Habelsberger \& Bhansing, 2021). The increasing use of digital channels can help galleries attain new clients that would be hard to approach due to geographical distance or would be afraid to enter the gallery. Consequently, it is believed to lead to an art market where the elites and everyone can get access (Arora \& Vermeylen, 2013).

Speed: Speed trumps perfection, one should not be paralyzed by the fear of failure, rather should move on and never stop, instead of waiting to see what happens. Gallery managers should take quick and decisive action to deal with the impact of the pandemic, this means taking the bull by the horn by being brave, bold, creative, and innovative. This infers anticipating challenges, being proactive, and exiting from potential problems.

A gallery's ability to swiftly address the current challenges depends on the type of culture such a gallery has created before now. To best respond to the situation, galleries would require adopting the no-nonsense, just-do-it approach, embracing innovations that tend to strengthen the gallery. The internet, for instance, has facilitated the 
global visibility of art market participants, making it easier for buyers and collectors to access a broader range of offerings on an international level, (Hebelsberger \& Bhansing, 2021). This has transformed the traditional gallery business model, yet not all galleries act with speed to have adopted this advanced business model.

\section{Achieving Excellence in Art Gallery Management}

As we move ahead now, we once again must face these challenges of art gallery management in times like this as opportunities to conquer the uncertain bold action we have taken today. Hesitancy in taking a bold step is a losing position. We need to reset and rejig our priorities and initiative to handle this change. Art gallery managers need to be creating cultures of people first. The business model of our people in the visual art sub-sector includes clients profit-making, which has radically changed the business of art gallery management with a commodity of exceptional appeal.

When art gallery management is people oriented, and employees and affiliates are treated with humanity, there will be a shift in their commitments to deliverables, thus creating a culture that promotes retaining their best in the industry. When managers of art galleries stop seeing employees and affiliates as disposable and start giving perks and benefits and truly leading with empathy rather than just around a buzzword or two, we will see meaningful changes in the way galleries/museums become effective in a pandemic. Collective leadership is a great way to manage uncertainty. In effect, a people centric approach self-develops a culture of being appreciated, respected, and trusted, such a culture on its own is an enabler of high performance. In turn, a cycle of appreciation emanates among employees, affiliates, and the management. Job satisfaction depends mainly on employee motivation; this could be moral or material motivation. Adapting to management culture through trust is key to preparing for and responding to change.

In the business of art gallery management today, we need to react with urgency and creativity, steadfast belief and resolve to recover and do so quickly. We need to conquer the uncertainty with bold action. Hesitancy, as earlier said, is a losing proposition. There is a need for art gallery managers to reinvent themselves through the nextnormal operating models. Next to normal refers to that which is un-normal. This is because we will never be the same again after the pandemic that shook the world in 2020. Our workplaces have changed, we all view life differently. How are we going to proffer solutions to our future? As an opportunity or as an impediment?

For managers, this is the time to recognize the extraordinary circumstances we live in and apprehend the un-normal. This is the reset. As Chief Executives of Art Galleries, this is the time to re-define your revered position through the culture you established. Your vision means more than ever to employees and affiliates who look to you for direction as their most important metric of all.

\section{Conclusion}

Before 2020, it was customary for gallery operators to manage the business in the traditionally established ways with a modicum of skills. Today, we must pursue a growth plan based on the right values. We need to think much more prominent and strive to create a collective better future for the business of art gallery management.

The financial crisis experienced by art gallery operators and the Covid-19 pandemic are ample proof that no organization can thrive on extant modules of doing business. To create a collective better future, stewardship is required based on the mindset and practice of creative value by integrating the needs of all stakeholders, society and peculiar environment.

The way forward is to think out of the box. Today, we are confronted with a generation of digitally empowered customers, hence the need to go digital for a new and better improved art gallery management to achieve excellence.

Any art gallery that fails to rise to the challenge risks becoming irrelevant. An art gallery manager should be someone who thinks, acts quickly in tight situations like this imposed by the pandemic, and be adept in dealing with diverse types of operations like virtual marketing, web creations, in-person communication, robust social media drive with the ability to design webinars, etc; to facilitate advertisement and sales online. The manager should be one with a sustained interest in the business, hence the need to be focused on creating intercultural programmes with local 
and international cultural organizations, the need to engage artists with in-gallery and outreach activities constantly should not be focused on creating intercultural programs undermined. Art gallery managers; corporate, public, and private operators should reflect on their management strategies in the current dispensation and interrogate where they think they would like to take it next. As we all know, the artist is the life of any art gallery. Without exhibitions to install or art fairs to attend, the future appears bleak for the artist. Do not despair, as you can view a completely new horizon from the comfort zone of private online exhibitions.

\section{References}

Arora, P., Vermeylen, F., (2013) Art Markets in Ruth Towse and Christian Handke (Eds.) Handbook on the Digital Creative Economy. Cheltenham and Northampton: Edward Elgar Publishing. https://doi.org/10.4337/9781781004876

Bartik, A.W., Bertrand, M., Cullen, Z., \& Glaeser, E.L., (2020) The Impact of Covid-19 on Small Business outcomes and expectations, Proceedings of the National Academy of Sciences of the United States of America. 117 (30) 17656-17666. https://doi.org/10.1073/pnas.2006991117

Belcove, J., (2021) From Online Exhibitions to E-commerce: Art Galleries are turning to the Digital World to Survive Covid-19, Robb Report. https://www.robbreport.com/shelter/art-collectibles/art-galleries-digital-push-amidcovid-19-2918893/amp/ (Retrieved on 9th February, 2022).

Carnell, J., (2011) The Covid-19 pandemic has Reshaped the Art of Selling Artworks, Econo Times. https://www.econotimes.com/The-COVID-19-Pandemic-Has-Reshaped-The-Art-of-Selling-Artwork-1608785 (Retrieved on 16th January, 2022).

Ernst \& Young LLP., (2012) The Digitisation of Everything: How Organisations Must Adapt to Changing Consumer Behaviour, UK. https://www.academia.edu/23705650/The digitisation of everything How organisati (Retrieved on 29th January, 2022).

Fillitz, T., (2014) The Booming Global Market of Contemporary Art, Focaal-Journal of Global and Historical Anthropology, 2014 (69) 84-96. https://doi.org/10.3167/fcl.2014.690106

Gain, J., (2021) The Key to Transparency Trust, Management 3.0. https://management30.com/blog/the-key-totransparency-trust/ (Retrieved on 9th February, 2022).

Gerlis, M., (2020) How Covid-19 has Forced the Art Market's Speedy Digital Conversion. https://www.theartnewspaper.com/2020/05/05/how-covid-19-has-forced-the-art-markets-speedydigital-conversion (Retrieved on 2nd February, 2022).

Gulbert, G., \& Hyde, I., (2021) Analysis: Covid-19's Impacts on Arts and Culture, COVID-19 RSFLG Data and Assessment Working Group COVID-19 Weekly Outlook.

Habelsberger B.E.M., Bhansing P.V., (2021) Art Galleries in Transformation: Is Covid-19 Driving Digitalization?, Arts, 10(3) 48. https://doi.org/10.3390/arts10030048

International Labour Organisation (2020) The Covid-19 Pandemic's Impact on the World of Work, International Labour Organisation. https://www.ilo.org/infostories/en-GB/Campaigns/covid19/globalcall\#intro (Retrieved on 2nd February, 2022).

Jeffrey, D., (2020) How Creativity Builds Resilience in Times of Crises, Psychology Today.

King S., (2018) What is Adaptation Theory?, sciencing Leaf Group Ltd.

Koshal, O., (2011) Difference Between Gallery and Museum, Difference Between.com https://www.google.com/amp/s/www.differnce-between-gallery-and-vs-museum/amp/ (Retrieved on 27th October, 2021).

McAndrew, C., (2020) The Impact of COVID-19 on the Gallery Sector, Art Basel and UPS, Basel. 
Nyah, A., Uduak, P., Ukim, I., (2020) Art Practice and the Role of Artists in a Global Pandemic in Katie McDowell (Ed.) Australian Journal of Arts \& Scientific Research, Vol. 25 No. 1. Queensland, Australia: Centre for Research and Development, CQ University.

Robinson, J., (2020) Pandemic. shttps://www.webmd.com/cold-and-flu/what-are-epidemics-pandemics-pandemicsoutbreaks. (Retrieved on 27th October, 2021).

Sutton, B., (2020) Gallery Sales Dropped 36\% as Art Market Reeled From Pandemic, Artsy. https://www.artsy.net/article/artsy-editorial-gallery-sales-dropped-36-art-market-reeled-pandemic/amp (Retrieved on 21st January, 2022).

Team Artenal (2020) 4 Ways Galleries and Art Organizations are Staying Creative Through Covid-19, Arternal. https://www.artenal.com/blog/4-ways-galleries-and-art-organizations-are-staying-creative-through-covid19/ (Retrieved on 29th January, 2022).

Turner, D., Developing Resilience in Managers, Slide Player. https://www.sheffield.ac.uk/polopoly fs (Retrieved on 22nd January, 2022).

Van Miegnet, H., Alexander, K. \& Leunissen, F., (2019) Imperfect Data, Art Markets and Internet Research, Arts, 8 (3) 76. https://doi.org/10.3390/arts8030076

Velthuis, O., (2011) Art Markets in Ruth Towse (Ed.) A Handbook of Cultural Economics, 2nd Edition, Edward Elgar Publishing. https://doi.org/10.4337/9780857930576

Velthuis, O., (2014) The Impact of Globalization on the Contemporary Art Market: The Traditional Gallery Model at Risk, Bloomsbury, London.

Funding: No funding was received for conducting this study.

Conflict of Interest: The Authors have no conflicts of interest to declare that they are relevant to the content of this article.

\section{About The License}

(C) The Author(s) 2022. The text of this article is open access and licensed under a Creative Commons Attribution 4.0 International License

\section{Cite this Article}

Best Ochigbo \& Ime Ukim, Achieving Excellence in Art Gallery Management in A Global Pandemic, Asian Journal of Interdisciplinary Research, 5(1) (2022) 19-25. https://doi.org/10.54392/ajir2213 